\title{
EFFECTS OF EDAPHIC CONDITIONS ON SITE QUALITY FOR SALIX PURPUREA 'HOTEL' PLANTATIONS ACROSS A LARGE CLIMATIC GRADIENT IN CANADA
}

\author{
Joel Ens ${ }^{1}$, Richard E. Farrell ${ }^{1}$ and Nicolas Bélanger ${ }^{2,3 *}$
}

${ }^{1}$ Department of Soil Science, University of Saskkatchewan, 51 Campus drive, Saskatoon, SK, S7N 5A8, Canada

${ }^{2}$ Téluq, Université du Québec, 5800, rue Saint-Denis, Bureau 1105, Montréal, QC, H2S 3L5, Canada

${ }^{3}$ Centre d'étude de la forêt, Université du Québec à Montréal, C.P. 8888 Succ. Centre-Ville, Montreal, QC, H3C 3P8, Canada

* Corresponding author, belanger.nicolas@ teluq.ca 


\begin{abstract}
Willow has been identified as a possible species for supplying large quantities of biomass for bioenergy and wood fibers in Canada. However, before site selection occurs, there is a need to know how the soils and climate of the prairies and central regions affect willow productivity. Soil, foliar, and climatic variables were therefore measured along with yields at nine "first rotation" Salix purpurea 'Hotel' plantations from central Alberta to southern Ontario. Correlation analysis was used to identify those parameters having the most influence on yields. Relationships between soil and climate and growth were established by regression analysis. The acid-base status of the soil as dictated by bulk elemental composition, in particular the presence of Ca, was found to be the dominant factor affecting productivity $\left(\mathrm{r}^{2}=0.967, P<0.001\right.$ total Ca vs. yields) despite large regional differences in climate. From a nutritional standpoint, total soil $\mathrm{N}(\mathrm{r}=0.743, P<0.048)$ and foliar $\mathrm{K}\left(\mathrm{r}^{2}=0.938, P<0.009\right.$ for sites with adequate moisture $)$ were positively correlated with growth. S. purpurea 'Hotel' yields were found to be primarily limited by water availability at the two lowest productivity prairie sites. Soil total $\mathrm{Ca}$ concentration, $\mathrm{pH}$ and total organic $\mathrm{C}$ concentration were all generally correlated with higher yields. Additional deficiencies appeared in the following order of importance: water $>\mathrm{N}$ and $\mathrm{K}>$ Mg. As a whole, soil properties were the dominant predictors of 'Hotel' growth in this study, which suggests that, even at the regional scale, growth was governed in large part by the capacity of soils to retain water and/or nutrients. Climate played a lesser role, except perhaps at two sites which appeared to receive inadequate moisture.
\end{abstract}

Keywords: Biomass energy; Short rotation intensive culture; Fast growth; Yields; Soil nutrient availability; Foliar nutrition; Calcium; Nitrogen; Potassium. 


\section{Introduction}

There is expanding interest in the use of fast growing tree species for both wood fiber and fuel. Using fast growing species in dedicated plantations reduces pressures on natural forests and can substantially reduce transportation costs. The Canadian prairies could provide an extensive land base for growing trees in a plantation setting. However, there are challenges for tree growth as this region is characterized by short and dry growing seasons and harsh cold winters (Padbury et al. 2002). As such, native tree growth is often limited to depressions, north facing slopes and more northern regions where evapotranspiration rates are decreased by cooler temperatures (Richards and Fung 1969; Padbury et al. 2002).

Despite being water demanding, Populus and Salix can return economically viable yields under various environmental conditions and plantation designs (Cardias Williams and Thomas 2006; Devine et al. 2010; Cao et al. 2011; Nelson et al. 2012). Populus and Salix spp. have been widely used in the Canadian prairies in shelterbelts to prevent soil erosion and conserve soil moisture (Schroeder 1988) and have been identified as having reasonable juvenile plantation yields despite the unfavorable conditions (DesRochers and Thomas 2003; Pinno et al. 2010).. Tree yields are greater in British Columbia, Ontario and Quebec than in the prairie provinces, but the prairies offer a larger and less expensive land base (McKenney et al. 2004). Salix spp. (later referred to as 'willow' for simplicity) are relatively new to agroforestry use in Canada but they do offer some advantages. For one, there is tremendous natural diversity of willow, with over 450 species worldwide having been identified (Argus 1997), which provides opportunity for breeding programs, using native species and/or non-native species, to tailor hybrids for specific needs (Kopp et al., 2001a). Willow regrows vegetatively and responds well to coppicing (Volk et al. 2004). Depending on planting and management style, rotation lengths can be short (typically 3-5 
years) and the trees will stay vigorous for several rotations (Mitchell et al. 1999; Volk et al. 2004). This addresses the need for producers to recover costs as soon as possible. It also enables a producer to harvest stems damaged by pests and extreme weather and restore vigor to the plant in the process. Thus, willow is well suited to short rotation intensive culture (SRIC) on the Canadian prairies.

If willow is to be planted as SRIC in Canada, then knowledge of how it will respond to varying soil and climate conditions, in terms of productivity, needs to be examined to ensure that plantations are established in appropriate locations and productivity can be maintained well into the future without overuse of irrigation and nutrient amendments that would unnecessarily increase the water and energy demands of the system (Bhardwaj et al. 2011). Site quality index, which is the height of the dominant trees for a given location and management regime at a chosen base age is the most commonly used estimate of productivity in forestry (Ung et al. 2001). For high density willow plantations, this system could be adapted by substituting measures of biomass for height to closer reflect maximum biomass production as the desired outcome. Even so, because plantations are to be established in the context of afforestation, there are no pre-existing willow trees to measure site quality index for most sites before planting. Therefore, it is necessary to examine the underlying soil and climatic factors controlling site productivity for willow grown under a wide range of Canadian soil and climatic conditions. Specific limiting factors must be identified, after which the relationships between these variables and willow growth can be used to assess the quality of a site without directly measuring the traditional site quality index.

Research thus far has concluded that willow grows best in loamy soils with a well developed structure and a rooting depth of $45 \mathrm{~cm}$ or more (Abrahamson et al. 2002). Ledin and 
Willebrand (1995) concluded that, in general, SRIC requires a soil with a minimum depth of 1 m. Willow has been found to establish slowly on soils with high clay content but it has been suggested that productivity may be greater in these soils in successive rotations (Abrahamson et al. 2002). Clayey soils are difficult to penetrate for young roots but have a much larger exchange capacity, thereby maintaining better nutrition of rapidly growing trees. Excessively well or poorly drained soils or soils with a $\mathrm{pH}$ lower than 5.5 or higher than 8.0 have been shown to limit productivity (Mitchell et al. 1999; Abrahamson et al. 2002).

Willow yields in Canada are on average lower than that achieved in the United States and parts of Europe owing in large part to a limited growing season (Mitchell et al. 1999). Moreover, the fast growing nature of willow requires a steady supply of water and nutrients for optimal growth. Although Lindroth and Cienciala (1996) reported a relatively high water use efficiency (WUE) for S. viminalis $\left(6.3 \mathrm{~g} \mathrm{~kg}^{-1}\right)$, a moderate value for annual precipitation on the Canadian prairies of $430 \mathrm{~mm}$ would produce a maximum of only $10 \mathrm{Mg} \mathrm{ha}^{-1} \mathrm{yr}^{-1}$. Thus, the low amount of precipitation in the Canadian prairies has been expected to greatly hinder willow growth such that the importance of fertility is diminished. Additionally, Guidi et al. (2008) concluded that increasing the available nutrients for willow also increases transpiration. In a water limited region, this would translate to underutilization of already limited moisture.

Willow has frequently been shown to respond favorably to fertilization, particularly with N (Adegbidi et al. 2003), both from synthetic and organic amendments (Labrecque et al. 1998). However, when planted on fertile arable land response to fertilizers may be minimal early in the plantation life-cycle (i.e. <10 years) (Mitchell et al. 1999). As such, amendments should be applied only where there is a need and should not be a common prescription for every site. What needs further examination (notably in Canada) is the potential for willow growth given soil and 
climatic factors at a variety of sites and an estimate of the ability of these sites to achieve optimal nutrient status before adding amendments.

There are many factors including soil $\mathrm{pH}$ and ionic concentrations of other nutrients that affect the ability of a plant to take up essential nutrients. Adegbidi et al. (2003) found that although willow initially responded similarly to a single input of either $\mathrm{N}$-fertilizer or organic amendments (sewage sludge or manure), the increase in growth associated with the organic amendments continued over a longer period of time. Maintaining a continual supply of the required nutrients for willow growth depends upon the nutrients present within the soil and its capacity to store and exchange ions and water. Thus, soil $\mathrm{C}$ and organic matter are critical for maintaining beneficial soil properties. It is therefore important to examine both the response in willow growth to soil and climate variables as well as how different soils are meeting the nutritional needs of willow by examining foliar nutrient levels.

Simon et al. (1990) described foliar nutrient levels of willow spp. leaves, stems and whole plants grown with no nutrient limitations by employing a nutrient solution maintained at optimum levels for the species. Although there was considerable variation, particularly with $\mathrm{N}$, this does provide a useful reference for willow nutrition at its optimum. Foliar N, P, and K concentrations were respectively $28.4,1.8$, and $19.0 \mathrm{mg} \mathrm{g}^{-1}$ for S. eriocephala, 35.4, 2.3 and 22.0 $\mathrm{mg} \mathrm{g}^{-1}$ for $S$. exigua, and 28.0, 1.9, and $23.4 \mathrm{mg} \mathrm{g}^{-1}$ of dry weight for S. lucida. Similarly, Kopinga and van den Burg (1995) reported optimal foliar nutrient concentrations for willow at $\mathrm{N}$ $>22, \mathrm{P}>2.1, \mathrm{~K}>19$, and $\mathrm{Mg}>3.0 \mathrm{mg} \mathrm{g}^{-1}$. These values are much lower than those reported by Cornelissen et al. (1997) who found $S$. caprea to have the highest N (43.0 $\left.\mathrm{mg} \mathrm{g}^{-1}\right), \mathrm{P}\left(6.53 \mathrm{mg} \mathrm{g}^{-}\right.$ ${ }^{1}$ ), and $\mathrm{K}\left(32.4 \mathrm{mg} \mathrm{g}^{-1}\right)$ foliar concentrations of 34 temperate deciduous and coniferous trees species. The N and K requirements of willow spp. identified by Simon et al. (1990) and Kopinga 
and van den Burg (1995) would similarly be at the high end of nutrient levels in Cornelissen et al. (1997) ( $\mathrm{N}$ ranges from 13.1-32.9 $\mathrm{mg} \mathrm{g}^{-1}$ and $\mathrm{K}$ from $6.1-21.7 \mathrm{mg} \mathrm{g}^{-1}$ excluding S. caprea), though P concentrations were more moderate (1.08-5.71 $\mathrm{mg} \mathrm{g}^{-1}$, excluding $S$. caprea). Calcium, which is the final nutrient examined in this study, can exhibit considerable variation in concentrations in leaves with species and with development stages (Jones 1998). The higher demand for nutrients of willow (Simon et al. 1990; Mitchell et al. 1999) compared to many other temperate tree species (Cornelissen et al. 1997; Alriksson and Eriksson 1998) may mean that productivity is controlled more by soils than by climate unlike other temperate species (Post and Curtis 1970; Chen et al. 1998; Ung et al. 2001; Hogg et al. 2005). It is therefore hypothesized that site quality will be dependent primarily on soil factors and that climate will be responsible for less of the variability in production observed between sites. This pattern could be influenced by geographic scale. For example, regional-scale studies (Ung et al. 2001; Hogg et al. 2005), having large climatic gradients, place more importance on the impact of climate on tree growth, whereas local-scale studies (Pinno et al. 2009; Pinno and Bélanger 2011), having small climate gradients, place more emphasis on the effects of soils - in particular those factors that dictate nutrient availability—on tree productivity.

Despite increasing interest in willow as a SRIC crop in the Canadian prairies, there is little available data for determining suitable site quality. The objective was therefore to measure soil and climate variables as well as productivity and nutrition across a broad range of sites in Canada to determine which set of conditions are conducive to greater growth. It was hypothesized that, due to willow's high nutrient demand and the broad range of soil present in Canada, soil, and in particular nutrient status, will be dominant over climate in controlling 
willow productivity. In testing this hypothesis, high and low site quality for willow production were characterized.

\section{Materials and Methods}

There is a broad range of climate conditions across the Canadian prairies and southern Ontario and as such this was expected to have an impact on willow growth. Included in this study were nine sites following a transect from the northwestern to southeastern boundaries of the Canadian prairies and extending into southern Ontario (Table 1). Much of the climate diversity of the prairie region was included in this study, with the exception of the driest regions of southern Alberta and Saskatchewan. As a generalization, there are longer and warmer growing seasons and more precipitation towards the southeast. At the northern bounds of the Canadian prairies, evapotranspiration decreases and in turn so does the water deficit, leading to the growth of native forests despite only modest gains in precipitation compared to the southern prairies.

Climate data for the years in which the trees grew were modeled using the BioSIM model (Régnière 1996), which typically yields a coefficient $>0.98$ between measured and modeled values (Régnière and Bolstad 1994). The BioSIM model used real data collected from surrounding Environment Canada weather stations to model site specific conditions where weather stations did not exist. Total annual precipitation, summer precipitation, vapor pressure deficit, potential evapotranspiration and aridity index were all modeled in this way. Degree days were calculated at both the $5^{\circ} \mathrm{C}$ and $10^{\circ} \mathrm{C}$ bases from the results of the BioSIM model.

At each site, the 'Hotel' clone of Salix purpurea was planted in triple rows with $60 \mathrm{~cm}$ spacing between trees and $200 \mathrm{~cm}$ between rows. This clone was selected largely for logistical reasons, as planting stock (unrooted cuttings) was readily available. Expected S. purpurea 
'Hotel' yields were moderate to low when compared to other clones bred as bioenergy feedstock. However, this clone has been relatively resistant to cold, herbivore and disease damage. Soil and foliar samples were collected during the third year of the first rotation from five plots at each plantation. Plots were $3.2 \mathrm{~m} \times 1.8 \mathrm{~m}$ and contained nine trees according to the original planting as well as a proportional representation of in row and between row area. There were several rows of buffer trees of S. purpurea 'Hotel' around each plot.

Soil and leaf samples were collected at all sites. However, two of the nine sites included in this study for nutritional analysis, i.e. ELL and BIR, were coppiced a year before sampling. This left only seven sites that had accumulated three years of growth, which is the general rotation length. GUE had been coppiced after the first year of growth but was allowed to still accumulate biomass for three years afterwards. While coppicing is typically implemented with the purpose of increasing biomass production via promoting branching to form multiple stems, $S$. purpurea 'Hotel' branches readily and, as such, there were no strong morphological differences between GUE and other sites. GUE willow did have an advantage in that the root system had an extra year of growth compared to other sites but it was deemed that this difference was within the variability associated with variance in management across the large scale of this study. Thus, for the sake of studying the factors regulating aboveground biomass production, only sites with three years of aboveground biomass accumulation were considered $(n=7)$, whereas all sites $(n=9)$ were included for linking soil fertility to foliar nutrition.

Within each plot, soils were sampled at $0-20 \mathrm{~cm}$ and $20-40 \mathrm{~cm}$ increments (3 subsamples). Soils were analyzed for total organic $\mathrm{C}$, total $\mathrm{N}$, inorganic $\mathrm{N}$ forms $\left(\mathrm{NO}_{3}\right.$ and $\left.\mathrm{NH}_{4}\right)$, bulk elemental composition (e.g. total $\mathrm{Ca}$, total $\mathrm{K}$ and total $\mathrm{Al}$ ), acid leachable $\mathrm{P}$, exchangeable $\mathrm{K}, \mathrm{Ca}, \mathrm{Mg}, \mathrm{Na}, \mathrm{Fe}$ and $\mathrm{Al}, \mathrm{pH}$, sand, silt, and clay. Soil $\mathrm{C}$ and $\mathrm{N}$ were determined by combustion 
at $800^{\circ} \mathrm{C}$ and infrared detection on a LECO CNS-2000 (LECO Corporation, St. Joseph, MI). Nitrate and $\mathrm{NH}_{4}$ were extracted using 2.0 $\mathrm{M} \mathrm{KCl}$ and analyzed on a Technicon Auto-Analyzer (Technicon Instruments Corporation, Tarrytown, NY). Acid leachable P was extracted from the soil with concentrated $\mathrm{H}_{2} \mathrm{SO}_{4}$ and measured with a SmartChem Instrument (Mandel Scientific Company Inc., Guelph, ON). Exchangeable $\mathrm{K}, \mathrm{Ca}, \mathrm{Mg}, \mathrm{Na}, \mathrm{Fe}$, and $\mathrm{Al}$ were extracted using a $0.1 \mathrm{M} \mathrm{BaCl}_{2}$ solution (Hendershot et al. 2007) and analyzed by atomic emission (K, Na) and absorption (Ca, Mg, Fe, Al) (SpectraAA 220, Varian Analytical Instruments). Soil pH was measured in a 2:1 water to soil suspension. Particle size distribution (soil texture) was analyzed on a Horiba Partica LA-950 laser particle analyzer (Horiba Instruments, Irvine, CA) and corrected for clay content using the pipette method (Kroetsch and Wang 2008). The bulk elemental composition of the upper $20 \mathrm{~cm}$ of soil was determined by X-ray fluorescence spectroscopy following the procedure described in Bélanger et al. (2004).

Fifty upper canopy leaves were randomly collected from within each plot in early August of the year harvested (i.e. 2007 and 2008), weighed, dried and ground in bulk for foliar analysis. Stems were harvested and weighed in the field for fresh weight once leaves had senesced. In the event that total leaf fall had not yet occurred, leaves were first removed manually before harvesting stems. Fresh weight of the stems was measured in the field. A 1-2 kg subsample, incorporating whole stems, was dried and reweighed to convert fresh weight to dry weight. Leaves were analyzed for concentrations of $\mathrm{C}, \mathrm{N}, \mathrm{P}, \mathrm{K}, \mathrm{Ca}, \mathrm{Mg}$, and $\mathrm{Na}$. Carbon and $\mathrm{N}$ of leaves were determined by infrared detection on a LECO CNS-2000 at $800^{\circ} \mathrm{C}$. Phosphorus, $\mathrm{K}$, Ca, and $\mathrm{Mg}$ concentrations of leaves were determined from a concentrated $\mathrm{H}_{2} \mathrm{SO}_{4}-\mathrm{H}_{2} \mathrm{O}_{2}$ digest (Kalra and Maynard 1999). Concentrations of $\mathrm{PO}_{4}$ were measured with a SmartChem Instrument. 
Potassium, $\mathrm{Ca}, \mathrm{Mg}$, $\mathrm{Na}$ were determined by atomic absorption ( $\mathrm{Ca}, \mathrm{Mg}, \mathrm{Fe}, \mathrm{Al})$ and emission $(\mathrm{K}, \mathrm{Na})$ spectroscopy.

After weighing, the stems were chipped $(5-10 \mathrm{~mm})$ and mixed to ensure homogeneity. Two samples (per plot) of approximately $40 \mathrm{~g}$ were then prepared by grinding in stages to produce a very fine homogeneous powder $(<60 \mu \mathrm{m})$. The two samples were prepared as a mix such that percentage from any one year was proportional to the growth increment that year (i.e. first year of growth is small relative to the third year). A $1.0 \pm 0.15 \mathrm{mg}$ subsample of that powder was analyzed for ${ }^{13} \mathrm{C} /{ }^{12} \mathrm{C}$ ratio using a continuous flow isotope ratio mass spectrometer interfaced with a RoboPrep Sample Converter (Europa Scientific, Crewe, UK). The working standard for $\delta^{13} \mathrm{C}$ determination was lentil (Lens culinaris) straw with a $\delta^{13} \mathrm{C}$ of $-27.6 \%$ relative to the PeeDee belemnite standard. The $\delta^{13} \mathrm{C}$ of the sample was calculated as followed:

$$
\delta^{13} C=\frac{R_{\text {sample }}-R_{\text {stan dard }}}{R_{\text {sample }}} \times 1,000
$$

where $R_{\text {sample }}$ and $R_{\text {standard }}$ are the ratios of ${ }^{13} \mathrm{C} /{ }^{12} \mathrm{C}$ in the sample and standard, respectively. The $\delta^{13} \mathrm{C}$ signature was used as an indicator of water stress. It is an integrative measure of WUE (whole growing season) in arid regions where minimal variation is observed for other environmental factors (McNulty et al. 1995; Stewart et al. 1995). Some of our study sites located in the semi-arid prairies have potential evapotranspiration exceeding precipitation. Also, the use of an identical willow clone and management practices at all sites reduced the variability among other environmental factors. Therefore, the major factor controlling foliar $\delta^{13} \mathrm{C}$ values should be soil water availability as affected by site and soil properties.

Relationships between harvested biomass and each soil, plant nutrient or climate variable were determined using the Pearson product-moment correlation. However, many of the relationships were non-linear in which case non-linear regression was used. Stepwise and 
forward multiple linear regression were used to determine which measured parameters would work best together to predict yields at the 7 study sites. The maximum number of variables selected in the multiple regression analysis was set at three in the interest of achieving parsimonious relationships while still utilizing the predictive capability of the analyses (Pinno and Bélanger 2011). Relationships at $P=0.05$ were considered significant. Statistical analyses were carried out with CoStat (CoHort Software, Monterey, CA).

\section{Results}

Across sites, soils were highly varied from acidic sandy loams $(\mathrm{pH}=5.1)$ to slightly alkaline heavy clays $(\mathrm{pH}=8.3)$ (Table 1$)$. Nutrient content of soil was similarly wide-ranging (total $\mathrm{N}=1.75-3.03 \mathrm{mg} \mathrm{g}^{-1}$; acid leachable $\mathrm{P}=0.35-1.15 \mathrm{mg} \mathrm{g}^{-1}$; and exchangeable $\mathrm{K}=0.09-$ $\left.1.33 \mathrm{cmol}_{\mathrm{c}} \mathrm{kg}^{-1}\right)$. The large geographic scale of this study also meant climate and weather were also very diverse (mean annual precipitation $=382-971 \mathrm{~mm}$; and degree days base $5^{\circ} \mathrm{C}=1330-$ $2300{ }^{\circ} \mathrm{C}$ day) (Table 1). Therefore, it is unsurprising that there was a large range in productivity (5.3-22.8 $\mathrm{Mg} \mathrm{ha}^{-1}$ ) present across sites in response to the diversity of site characteristics (Table 1). In general, the 'Hotel' clone with the greatest yields tended to be on sites receiving adequate moisture (see summer precipitation in Table 2) with calcareous (Figure 2) medium textured soils (Figure 3). Sites with sandy soils, very low precipitation or a combination of both produced the lowest yields.

Few climate variables were correlated with yields of the 'Hotel' clone (Table 2). There was no relationship between yields and annual or summer precipitation over the course of three years. There was, however, a positive correlation between summer precipitation in the first two years of growth $(\mathrm{r}=0.752, P<0.051)$. 
Different plant species have unique $\delta^{13} \mathrm{C}$ signatures based on their intrinsic WUE and photosynthetic pathway (i.e., $\mathrm{C}_{3}$ vs. $\mathrm{C}_{4}$ plants). This means that there is no absolute baseline $\delta^{13} \mathrm{C}$ signature indicating water stress; rather that as the $\delta^{13} \mathrm{C}$ increases (becomes less negative), WUE increases in response to water scarcity and plants are likely more water stressed than others of the same species. Examination of $\delta^{13} \mathrm{C}$ values of the 'Hotel' stems confirms that there is no simple relationship between productivity and water stress across all sites (Figure 1). Rather, there are two distinct groups: SMO and UOS were the only two sites where moisture limitations crossed a threshold severe enough to limit productivity and caused these sites to have the highest $\delta^{13} \mathrm{C}$ values. At the other sites, $\delta^{13} \mathrm{C}$ values were positively correlated with harvestable biomass, indicating that factors other than water stress were more limiting for at least a number of these sites.

Site quality of the 'Hotel' clone was strongly correlated with bulk soil chemical composition (Table 3). Total Ca (Figure 2a) was the strongest single indicator of 'Hotel' yields as were soil $\mathrm{pH}$ (Figure $2 \mathrm{~b})$ and $(\Sigma$ Total $\mathrm{Ca}+\mathrm{Mg}) /(\Sigma$ Total $\mathrm{Si}+\mathrm{Al}+\mathrm{Fe})($ Figure $2 \mathrm{c})$. The latter variable is an indicator of the acid-base status of the soil (Birkeland 1999). Soil organic C was another general indicator of productivity (Table 3). Additionally, soil texture influenced productivity as the 'Hotel' clone grew best on medium textured soils with adequate drainage (Figure 3).

Foliar N was related to total soil N (Figure 4b), foliar K was related to soil exchangeable $\mathrm{K}$ (Figure 5c), and foliar $\mathrm{P}$ was related to soil leachable $\mathrm{P}$ (Figure 6b). However, foliar Mg and $\mathrm{Ca}$ were not related to soil (total or exchangeable) $\mathrm{Mg}$ and $\mathrm{Ca}$ (results not shown). When considering all seven sites for which we have yield data for three years, no significant positive correlations between foliar concentrations and yields of the 'Hotel' clone were found (Table 4). However, with the water stressed SMO and UOS sites removed from the dataset, the analyses 
revealed a statistically significant positive correlation coefficient between foliar $\mathrm{K}$ and willow yields (Table 4, Figure 5) and a marginally significant positive correlation coefficient between foliar N and yields (Table 4, Figure 4). After removing SMO and UOS from the foliar dataset, soil total $\mathrm{N}$ was still more strongly correlated with yields (greater $\mathrm{P}$ value) than was foliar $\mathrm{N}$ (Tables 3 and 4, respectively). Foliar Mg was only positively correlated with productivity at LAK, POR and PIC sites (Table 4).

None of the multiple linear regression models calculated via stepwise and forward regression were able to exceed the strength of the relationship described by a second order polynomial with total Ca (Figure 2a). Several models could be created by combining different variables with total Ca but these yielded slightly lower coefficients of determination (results not shown). In terms of secondary predictors, there is both a high degree of covariance among variables and relatively little room for improvement of the models such that multiple linear regressions, both stepwise and forward, were not able to adequately identify the most important nutritional or climatic requirements of willow.

\section{Discussion}

Degree days are useful in estimating the potential for plant productivity from a temperature standpoint (Wang 1960) and have been shown to be positively correlated $\left(r^{2}>0.95\right)$ with willow growth (Kopp et al. 2001b). Because of the large climatic gradient created in this study, it was therefore expected that greater annual precipitation and a longer growing season as reflected by degree days would have been somewhat important for determining productivity of the 'Hotel' clone. However, degree days did not explain the variability in average site yields. This is at odds with studies examining the growth of other tree species at the regional scale (Post and 
Curtis 1970; Lindroth and Båth 1999; Ung et al. 2001; Hamel et al. 2004; Hogg et al. 2005) and may be related to the high water and nutrient requirements of $S$. purpurea 'Hotel' or a possible effect of photoperiod across the range in latitude that was beyond the scope of this study.

Likewise, other climate variables had poor correlations with growth. Vapor pressure deficit, which is the difference between the actual water content of the air and the potential content of the air at a relative humidity of $100 \%$, is a good measure of the atmospheric control on transpiration. Potential evapotranspiration is similarly reflective of potential plant activity as it increases with increasing available solar radiation but can cause water stress if precipitation cannot meet demands. Aridity index, which is based on the ratio of precipitation to potential evapotranspiration, takes into consideration both the supply and use of water. However, none of these variables satisfactorily explained the variability in biomass production.

Soil properties were the dominant predictors of $S$. purpurea 'Hotel' growth in this study, which suggests that, even at the regional scale, growth was governed in large part by the capacity of soils to retain water and/or nutrients. Climate played a lesser role, except perhaps at two sites (i.e. SMO and UOS) which appeared to receive inadequate moisture. Site selection based on soil quality can thus result in minimizing the need for inputs such as irrigation and fertilizers (Bhardwaj et al. 2011), thereby keeping the water and energy footprints to a minimum and maximizing the environmental benefits of willow biomass production. The rationale for a large control from soils on the growth of the 'Hotel' clone is discussed in details below.

\section{Water availability}

The $\delta^{13} \mathrm{C}$ signatures of the 'Hotel' stems were correlated with total precipitation over three years across the sites $(\mathrm{r}=-0.789, P=0.028$, Table 4$)$ but not summer precipitation over the first 
two years of growth $(\mathrm{r}=-0.472, P=0.276$, Table 2$)$. This is despite that summer precipitation over the first two years of growth and harvested biomass were correlated $(\mathrm{r}=0.752, P=0.051)$. There was clearly more radial growth in the third year than the first two years and consequently, there was a higher percentage of wood from that third year in the sample compared with years 1 and 2. This means that the $\delta^{13} \mathrm{C}$ values were biased towards the third year. It also suggests that the critical first two years may be underrepresented relative to their importance in determining productivity.

Figure 1 indicates that, with the exception of SMO and UOS, as productivity rose from other factors (e.g. due to improved nutrition), photosynthetic rates increased. Higher rates of carbon gain increases WUE. In turn, faster growing plants in moisture limited regions may have exerted more pressure on dwindling moisture supplies, thus also increasing WUE (Moukoumi et al. 2012). Both of these conditions may have contributed to the positive correlation between $\delta^{13} \mathrm{C}$ and harvested biomass across the majority of sites. However, unless we measure gas exchange or water potential, it is not possible to determine whether carbon gain or water loss or both are responsible for the relationship between $\delta^{13} \mathrm{C}$ and yields.

The two sites with the lowest productivity (SMO and UOS) were those with the greatest $\delta^{13} \mathrm{C}$ values, though in this case they were probably negatively affected by severe water stress. The growth of 'Hotel' at SMO is supported by a soil with a very coarse texture and received an annual average of $432 \mathrm{~mm}$ of precipitation over the three year growing period. Further, although UOS is a clay soil, it experienced extended periods without rain, particularly in July 2007 [16.4 $\mathrm{mm}$ of precipitation in July as compared to a $30 \mathrm{yr}$-normal of $60.1 \mathrm{~mm}$ (Environment Canada, 2011)]. It is therefore reasonable to conclude that the poor yields at these two sites are primarily 
a result of water stress due respectively to soil type and summer precipitation. Thus, while these two sites were limited by water stress, other sites were at least partially limited by other factors.

Soil texture and topography can have a large impact on water availability for plants. Coarse soils allow water to quickly drain such that even soils that receive adequate precipitation may not be able to retain moisture long enough to support high rates of plant growth, as per SMO. Likewise, topography can affect moisture availability by affecting water redistribution. However, this was likely not a factor as the study sites were mostly flat.

Productivity of willow plantations early in their establishment stage has been reported as greatest in medium textured soils (Mitchell et al. 1999; Abrahamson et al. 2002). Similarly in this study, medium textured soil produced the highest yields for the 'Hotel' clone (Figure 3). Negative correlations with sand content and positive correlations with silt content at $0-20 \mathrm{~cm}$ were found (Table 3). Mitchell et al. (1999) explained that willow requires soils with good drainage and that stagnating water will result in a decline in productivity. However, the stagnating water argument is improbable at this site, due to low precipitation and rather the $\delta^{13} \mathrm{C}$ data indicates the opposite, that it is related to a lack of moisture. In moisture limited regions, medium textured soils still produced the highest yield at 3 years presumably because sandy soils do not efficiently retain the water and nutrients required for willow growth, and heavier clay soils are likely too difficult for young roots to penetrate when dry.

Drought is common on the Canadian prairies but it is not the only weather associated limiting factor. Extreme cold in winter months is particularly hard on young shoots and some winter kill was noted at the UOS site, and nearly caused plantation failure at the BIR site. At the latter site, extreme cold during the winter (minimum daily temperatures $<-40^{\circ} \mathrm{C}$ ) was blamed for killing most of the aboveground biomass. To restore plant health, the S. purpurea shrubs were 
coppiced to encourage growth from the still healthy base of the plants. This made it impossible to compare the rates of productivity at the BIR site with other plantations but it does highlight the potential of extreme weather to limit the productivity of a plantation. Therefore, while it is still important to look at typical rates of precipitation and the length of growing season, it may be more important to look at the probability of extreme weather when evaluating the suitability of a site for willow production.

\section{Soil chemical composition}

Soil chemistry was a strong indicator for the productivity of the 'Hotel' clone. While soil texture appeared to have an impact on $S$. purpurea growth due to its influence on water retention, it seems that the acid-base status of the soil had a much greater control over yields. The elemental composition of the soil can be grouped into categories of elements that co-vary and thus are similarly associated with productivity. As a whole, total $\mathrm{Ca}$ and $\mathrm{Mg}$ were indicators of high growth rates, while total $\mathrm{Si}$ was related to poor productivity (Table 3 ). This indicates that soils containing calcite and dolomite were more conducive to willow growth than base-poor and acidic soils containing dominantly felsic minerals.

Dolomite and calcite weather faster than most Ca-rich minerals contained in felsic rocks (e.g. plagioclase, amphibole). In a young landscape that was "recently" glaciated, a soil that contains $\mathrm{Ca}$ and $\mathrm{Mg}$ bearing minerals that are easily dissolved (and thus leads to more available $\mathrm{Ca}$ and $\mathrm{Mg}$ ) will therefore be likely more productive. While we are unaware of studies showing such a relationship between total $\mathrm{Ca}$ and tree growth, a few studies with sugar maple indicated the benefits of total Ca-rich soils on growth variables, notably seedling survival and positive correlations with arbuscular mycorrhizal fungi (Kobe et al. 1995; Juice et al. 2006). Our results 
suggest that total chemistry of the soil, which is not a common soil analysis, can be a reliable indicator of tree growth, possibly providing different information than the most commonly tested exchangeable cations (Thiffault et al. 2006).

Calcium and $\mathrm{Mg}$-rich soils also create an environment that has an appropriate $\mathrm{pH}$ level which, in turn, is generally a good indicator for the suitability of a soil for plant growth as it affects cation exchange capacity of soils, soil microbial activity and nutrient availability for plants (Havlin et al. 2005). Soil pH was strongly (positively) correlated to total $\mathrm{Ca}(\mathrm{r}=0.938, \mathrm{p}<$ 0.001) and total $\mathrm{Mg}(\mathrm{r}=0.967, \mathrm{p}=0.002)$ (results not shown). S. purpurea 'Hotel' grew best in soils with a $\mathrm{pH}$ of approximately 8.3 but growth declined sharply below 7.0. Anything below a $\mathrm{pH}$ of 6.0 showed very poor productivity. This is higher than the site recommendations for willow spp. by Abrahamson et al. (2002) of between $\mathrm{pH}$ of 5.5 and 8.0 and by Mitchell et al. (1999) of between $\mathrm{pH}$ of 6.0 and 7.0.

Soil $\mathrm{C}$, due to its role in increasing soil fertility and moisture retention (Havlin et al. 2005), was positively correlated to S. purpurea 'Hotel' yields (Table 3). Higher soil C is generally associated with higher rates of primary productivity and, as such, would suggest that the soils most capable of supporting high rates of willow biomass production will also be the same soils producing the greatest yields for agriculture [i.e. soils high in total C (Christensen and Johnston 1997)]. However, the strong affinity for total Ca and $\mathrm{pH}>8.0$ exhibited by $S$. purpurea 'Hotel' may provide an exploitable niche from within agricultural regions. This study confirms that the growth of S. purpurea 'Hotel' (and likely other willow clones) in degraded soils or those low in soil C will exhibit lower yields. Ens et al. (2013) found that at 3 years from plantation establishment, soil C was depleted in Canadian SRIC of willow. However, should tillage decrease with establishment of perennial willow, soil $\mathrm{C}$ would be expected to increase [as was 
the case in Arevalo et al. (2011) in hybrid poplar plantations in Alberta, Canada, with net accumulation after 7 years] leading to a positive feedback of increased willow productivity and soil C over time.

\section{Willow Foliar Nutrition}

Although the ultimate goal of this study was to determine site quality from soils, foliar nutrition is a more direct measure of the status of the plants-thus, it was also used for determining site quality. When examining the effects of nutritional concentration of $S$. purpurea 'Hotel' as a predictor for productivity, it is important to consider that two sites were limited by water availability. With water stress, the potential effect of nutrient deficiencies on growth is masked. Thus, these sites were excluded from the dataset when trying to link foliar nutrients to tree growth. This assumes that water stress is not affecting any other site and that any nutrient deficiency has negligible effects on those plants experiencing water stress, no matter how severe the deficiency.

The two nutrients that had the strongest relationship with the growth of the 'Hotel' clone were $\mathrm{N}$ and $\mathrm{K}$, not $\mathrm{Ca}$ and $\mathrm{Mg}$ (Figures 4 and 5, Table 4). It is for this reason that the acid-base status of the soil is suspected to be a proxy for nutrient availability as a whole, not just for $\mathrm{Ca}$ and Mg. Total soil $\mathrm{N}$ was positively correlated with yield as well as foliar N (Table 3, Figure 4). The highest foliar $\mathrm{N}$ concentrations in the dataset were approximately $30 \mathrm{mg} \mathrm{N} \mathrm{g}^{-1}$, which falls in the range of optimum concentrations (22 to $35 \mathrm{mg} \mathrm{g}^{-1}$, depending on species) reported by Simon et al. (1990) and Kopinga and van den Burg (1995) (Figure 4). That foliar concentrations are approaching or are at optimum levels for LAK, POR and PIC may explain why there was no definite linear relationship between foliar $\mathrm{N}$ and productivity (Figure 4a). However, that GUE 
and SSM are both below ideal concentrations and experiencing low growth may well be due to the high $\mathrm{N}$ requirements of $S$. purpurea 'Hotel' for maximum growth.

The vast majority of soil total $\mathrm{N}$ is organic $\mathrm{N}$, but the inorganic $\mathrm{N}$ is the readily available fraction for plant uptake. Ens et al. (2013) observed a depletion of soil inorganic N under $S$. purpurea 'Hotel' relative to reference plots which served as a proxy for conditions before 'Hotel' was planted. The loss in soil inorganic $\mathrm{N}$ was attributed to faster growth of $S$. purpurea 'Hotel' and in turn, faster rates of uptake. The same effect was observed by Moukoumi et al. (2012) in pure willow plantations in Saskatchewan as well as intercroppings with the N-fixing caragana shrub.

The effect of K nutrition on S. purpurea 'Hotel' yields is shown by the strong relationship with foliar $\mathrm{K}$ and harvested biomass as well as soil exchangeable $\mathrm{K}$ and harvested biomass (Figure 5a,b). Below a leaf concentration of between 8.0 and $10.0 \mathrm{mg} \mathrm{K} \mathrm{g}^{-1}$, growth was severely impaired. This corresponds well with the threshold value for $\mathrm{K}$ deficiencies reported in the literature (Mengel 2007). Above a foliar concentration of $10.0 \mathrm{mg} \mathrm{K} \mathrm{g}{ }^{-1}$, S. purpurea 'Hotel' responded strongly to increasing concentrations of foliar K. Potassium also appeared sufficient to avoid severe deficiencies at soil exchangeable concentrations of $0.5 \mathrm{cmol}_{\mathrm{c}} \mathrm{kg}^{-1}$ both in terms of yield and foliar concentration (Figure $7 \mathrm{~b}, \mathrm{c}$ ). No upper bound where excess $\mathrm{K}$ was taken up was detected in this study.

From 0.4-1.2 $\mathrm{mg} \mathrm{g}^{-1} \mathrm{H}_{2} \mathrm{SO}_{4}$ leached soil $\mathrm{P}$, covering much of the range seen in this study, the foliar $\mathrm{P}$ concentration remained relatively stable near $2.0 \mathrm{mg} \mathrm{P} \mathrm{g}^{-1}$ (Figure $6 \mathrm{~b}$ ). This is the optimum nutrition of willow leaves as reported by Simon et al. (1990). Concentrations of foliar P varied from the optimum only where leachable soil $\mathrm{P}$ was at the extremes of the range of concentrations. This suggests that willow was able to effectively regulate $\mathrm{P}$ uptake within the 
range of conditions experienced in this study and as such, there was no discernible growth response of added $\mathrm{P}$ within this range (Figure 6a). Interestingly, the relationship between soil $\mathrm{P}$ and foliar P suggest that the acid leach is a good proxy for available soil P in SRIC of willow (Figure 6c). As such, should $\mathrm{H}_{2} \mathrm{SO}_{4}$ leached soil $\mathrm{P}$ at other sites be outside of $0.4-1.2 \mathrm{mg} \mathrm{g}^{-1}, \mathrm{P}$ uptake and nutrition will likely differ from the optimum.

Any possible effects of foliar $\mathrm{Mg}$ on willow growth were masked by acute water stress, $\mathrm{N}$ deficiencies or $\mathrm{K}$ deficiencies (Table 4). Foliar concentrations of $\mathrm{Mg}$ at high producing sites (LAK, POR, PIC) were as high as $4.0 \mathrm{mg} \mathrm{g}^{-1}$, which suggests the $>3.0 \mathrm{mg} \mathrm{g}^{-1}$ value for optimal nutrition reported by Kopinga and van den Burg (1995) is possibly low for S. purpurea 'Hotel'. Thus, Mg may increase in importance as deficiencies in water, $\mathrm{N}$ and $\mathrm{K}$ are alleviated. However, due to the low number of sites with adequate moisture, $\mathrm{N}$ and $\mathrm{K}$, there was no clear relationship between exchangeable soil $\mathrm{Mg}$ or foliar $\mathrm{Mg}$ and productivity, making prediction of $\mathrm{Mg}$ soil requirements for willow difficult.

Similarly, foliar Ca was also found to be correlated with the yields of S. purpurea 'Hotel' but its effects as a nutrient is inseparable from its effect as the key buffer for $\mathrm{pH}$ - therefore, it is difficult to discern Ca nutrition from soil analyses (Figure 2). Foliar Ca was not correlated with harvested biomass at sites not experiencing acute water stress, $\mathrm{N}$ deficiencies or $\mathrm{K}$ deficiencies (Table 4). While the full causation of soil $\mathrm{Ca}$ on productivity is unclear, the low productivity below 30-35 $\mathrm{mg} \mathrm{g}^{-1}$ of total Ca seen in Figure 2 indicates caution should be given to establishing willow on sites with low surface soil exchangeable Ca.

\section{Conclusions}


It appears that soil properties are the most important for estimating S. purpurea 'Hotel' yields from the Canadian prairies to southern Ontario. Prediction of site quality is possible given mainly soil data despite a large climatic gradient. Characteristics which affect water retention and nutrient availability are the most useful for predicting yields of S. purpurea 'Hotel'. The acid-base status of the soil as dictated by bulk elemental composition, in particular the presence of $\mathrm{Ca}$, was found to be the dominant control. From a nutritional standpoint, sites with total soil $\mathrm{N}$ and foliar K (for sites with adequate moisture) also had greater growth. Water availability was found to be primarily limiting yields the two lowest productivity prairie sites where moisture deficiencies overshadowed nutritional deficiencies. Thus, each site experienced its own unique combination of limiting factors: severe water stress $>\mathrm{N}$ and $\mathrm{K}$ deficiencies $>\mathrm{Mg}$ and $\mathrm{P}$ deficiencies. It is expected that as one limitation is removed through selection of optimal sites, another will become dominantly important. Therefore, yields of S. purpurea 'Hotel' can be explained by Liebig's Law of Minimum as stated by Taylor (1934) such that growth is limited largely by soil variables but that extreme environmental conditions can become limiting even though climate is not.

\section{References}

Abrahamson LP, Volk TA, Kopp RF, White EH, Ballard JL (2002) Willow biomass producer's handbook (Revised). SUNY-ESF, Syracuse, NY

Adegbidi HG, Briggs RD, Volk TA, White EH, Abrahamson LP (2003) Effect of organic amendments and slow-release nitrogen fertilizer on willow biomass production and soil chemical characteristics. Biomass Bioenerg 25:389-398 
Alriksson A, Eriksson HM (1998) Variations in mineral nutrient and C distribution in the soil and vegetation compartments of five temperate tree species in NE Sweden. For Ecol Manage 108:261-273

Arevalo CBM, Bhatti JS, Chang SX, Sidders D (2011) Land use change effects on ecosystem carbon balance: from agricultural to hybrid poplar plantation. Agric Ecosys Environ 141: 342-349

Argus GW (1997) Infrageneric classification of Salix (Salicaceae) in the New World. Syst Bot Monogr 52:1-121

Bélanger N, Paré D, Bouchard M, Daoust G (2004) Is the use of trees with superior growth a threat to soil nutrient availability? A case study with Norway spruce. Can J For Res $34: 560-572$

Bhardwaj AK, Zenone T, Jasrotia P, Robertson GP, Chen J, Hamilton SK (2011) Water and energy footprints of bioenergy crop production on marginal lands. GCB Bioenergy $3: 208-222$

Birkeland PW (1999) Soils and Geomorphology. Oxford University Press, Oxford, UK

Cao Y, Lehto T, Repo T, Silvennoinen R, Pelkonen P (2011) Effects of planting orientation and density of willows on biomass production and nutrient leaching. New Forests 41:361-377

Cardias Williams F, Thomas T (2006) Some key issues concerning current poplar production and future marketing in the United Kingdom. New Forests 31:343-359

Chen HYH, Klinka K, Kabzems RD (1998) Site index, site quality, and foliar nutrients of trembling aspen: relationships and predictions. Can. J. For. Res. 28:1743-1755.

Christensen BT, Johnston AE (1997) Chapter 18 Soil organic matter and soil quality-Lessons learned from long-term experiments at Askov and Rothamsted. Dev Soil Sci 25:399-430 
Cornelissen JHC, Werger MJA, Castro-Díez P, van Rheenen JWA, Rowland AP (1997) Foliar nutrients in relation to growth, allocation and leaf traits in seedlings of a wide range of woody plant species and types. Oecologia 111:460-469

DesRochers A, Thomas BR (2003) A comparison of pre-planting treatments on hardwood cuttings of four hybrid poplar clones. New Forests 26:17-32

Devine WD, Harrington CA, DeBell DS (2010) Intra-annual growth and mortality of four Populus clones in pure and mixed plantings. New Forests 39:287-299

Environment Canada. 2011. Canadian Climate Normals 1971-2000. Available at http://www.climate.weatheroffice.gc.ca/climate_normals/index_e.html? (accessed May 11, 2011)

Ens JE, Farrell RE, Bélanger N (2013) Early effects of afforestation with willow (Salix purpurea, 'Hotel') on soil carbon and nutrient availability. Forests 4: 137-154

Guidi W, Piccioni E, Bonari E (2008) Evapotranspiration and crop coefficient of poplar and willow short-rotation coppice used as vegetation filter. Bioresour Technol 99:4832-4840

Hamel B, Bélanger N, Paré D (2004) Productivity of black spruce and Jack pine stands in Quebec as related to climate, site biological features and soil properties. For Ecol Manage 191:239-251

Havlin JL, Beaton JD, Tisdale SL, Nelson WL (2005) Soil fertility and fertilizers: an introduction to nutrient management, 7th ed. Prentice Hall, New Jersey

Hendershot WH, Lalande H, Duquette M (2007) Ion Exchange and Exchangeable Cations. In: Carter MR and Gregorich EG (eds) Soil sampling and methods of analysis: second edition. CRC Press, Boca Raton, FL, pp 197-206

Hogg EH, Brandt JP, Kochtubajda B (2005) Factors affecting interannual variation in growth of western Canadian aspen forests during 1951-2000. Can J For Res 35:610-622

Jones JBJ (1998) Plant nutrition manual. CRC Press, Boca Raton, FL 
Juice SM, Fahey TJ, Siccama TG, Driscoll CT, Denny EG, Eagar C, Cleavitt NL, Minocha R, Richardson AD (2006) Response of sugar maple to calcium addition to northern hardwood forest. Ecology 87:1267-1280

Kalra YP, Maynard DG (1999) Methods manual for forest soil and plant analysis. Canadian Forest Service, Northern Forestry Centre, Edmonton, AB

Kobe RK, Pacala SW, Silander JA, Canham CD (1995) Juvenile Tree Survivorship as a Component of Shade Tolerance. Ecol Applic 5:517-532

Kopinga J, van den Burg J (1995) Using soil and foliar analysis to diagnose the nutritional status of urban trees. J Arboric 21:17-24

Kopp RF, Smart LB, Maynard CA, Isebrands JG, Tuskan GA, Abrahamson LP (2001a) The development of improved willow clones for eastern North America. For Chron 77:287292

Kopp RF, Abrahamson LP, White EH, Volk TA, Nowak CA, Fillhart RC (2001b) Willow biomass production during ten successive annual harvests. Biomass Bioenerg 20:1-7

Kroetsch D, Wang C (2008) Particle size distribution. In: Carter MR and Gregorich EG (eds) Soil sampling and methods of analysis: second edition. CRC Press, Boca Raton, FL, pp $713-726$

Labrecque M, Teodorescu TI, Daigle S (1998) Early performance and nutrition of two willow species in short-rotation intensive culture fertilized with wastewater sludge and impact on the soil characteristics. Can J For Res 28:1621-1635

Ledin S, Willebrand E (eds.) 1995. Handbook on how to grow short rotation forests. Swedish University of Agricultural Sciences, Department of Short Rotation Forestry, Uppsala, Sweden

Lindroth A, Cienciala E (1996) Water use efficiency of short-rotation Salix viminalis at leaf, tree and stand scales. Tree Physiol 16:257-262 
Lindroth A, Båth A (1999) Assessment of regional willow coppice yield in Sweden on basis of water availability. For Ecol Manage 121:57-65

McKenney DW, Yemshanov D, Fox G, Ramlal E (2004) Cost estimates for carbon sequestration from fast growing poplar plantations in Canada. For Policy Econ 6:345-358.

McNulty SG, Swank WT (1995) Wood $\delta^{13} \mathrm{C}$ as a measure of annual basal area growth and soil water stress in a Pinus strobus forest. Ecology 76:1581-1586

Mengel K (2007) Potassium. In: Barker AV and Pilbeam DJ (eds) Handbook of plant nutrition. CRC Press, Boca Raton, FL, pp 91-120

Mitchell CP, Stevens EA, Watters MP (1999) Short-rotation forestry - operations, productivity and costs based on experience gained in the UK. For Ecol Manage 121:123-136.

Moukoumi J, Farrell R, Van Rees K, Hynes R, Bélanger N (2012) Intercropping Caragana arborescens with Salix miyabeana to satisfy nitrogen demand and maximize growth. BioEnerg Res 5:719-732

Nelson AS, Saunders MR, Wagner RG, Weiskittel AR (2012) Early stand production of hybrid poplar and white spruce in mixed and monospecific plantations in eastern Maine. New Forests 43:519-534

Padbury G, Waltman S, Caprio J, Coen G, McGinn S, Mortensen D, Nielsen G, Sinclair R (2002) Agroecosystems and land resources of the Northern Great Plains. Agron J 94:251-261

Pinno BD, Paré D, Guindon L, Bélanger N (2009) Predicting productivity of trembling aspen in the Boreal Shield ecozone of Quebec using different sources of soil and site information. For Ecol Manage 257:782-789 
Pinno BD, Thomas BR, Bélanger N (2010) Predicting the productivity of a young hybrid poplar clone under intensive plantation management in northern Alberta, Canada using soil and site characteristics. New Forests 39:89-103

Pinno BD, Bélanger N (2011) Estimating trembling aspen productivity in the boreal transition ecoregion of saskatchewan using site and soil variables. Can J Soil Sci 91:661-669

Post BW, Curtis RO (1970) Estimation of northern hardwood site index from soils and topography in the Green Mountains of Vermont. Vermont Agric Exp Sta Bull 664:1-17

Régnière J (1996) Generalized approach to landscape-wide seasonal forecasting with temperature-driven simulation models. Environ Entomol 25:869-881

Régnière J, Bolstad P (1994) Statistical Simulation of Daily Air Temperature Patterns Eastern North America to Forecast Seasonal Events in Insect Pest Management. Environ Entomol 23:1368-1380.

Richards JH, Fung K-I (1969) Atlas of Saskatchewan. University of Saskatchewan, Saskatoon, SK

Schroeder WR (1988) Planting and establishment of shelterbelts in humid severe-winter regions. Agric Ecosys Environ 22-23:441-463

Simon M, Zsuffa L, Burgess D (1990) Variation in N, P, and K status and N efficiency in some North American willows. Can J For Res 20:1888-1893

Soil Classification Working Group (1998) The Canadian System of Soil Classification, $3^{\text {rd }}$ ed. NRC Research Press, Ottawa, ON

Stewart GR, Turnbull MH, Schmidt S, Erskine PD (1995) ${ }^{13} \mathrm{C}$ natural abundance in plant communities along a rainfall gradient: a biological integrator of water availability. Aust $\mathrm{J}$ Plant Physiol 22:51-55 
Taylor WP (1934) Significance of extreme or intermittent conditions in distribution of species and management of natural resources with a restatement of Liebig's Law of Minimum. Ecology 15:374-379.

Thiffault E, Paré D, Bélanger N, Munson A, Marquis F (2006) Harvesting intensity at clearfelling in the boreal forest. Soil Sci Soc Am J 70:691-701.

Ung CH, Bernier PY, Raulier F, Fournier RA, Lambert MC, Régnière J (2001) Biophysical site indices for shade tolerant and intolerant boreal species. For Sci 47:83-95

Volk TA, Verwijst T, Tharakan PJ, Abrahamson LP, White EH (2004) Growing fuel: a sustainability assessment of willow biomass crops. Front Ecol Environ 2:411-418

Wang JY 1960. A critique of the heat unit approach to plant response studies. Ecology 41:785790 
Table 1 Site names, locations, history, soil texture, soil $\mathrm{pH}$, bulk density, precipitation and harvested biomass summary data for the nine studied S. purpurea 'Hotel' plantations

\begin{tabular}{|c|c|c|c|c|c|c|c|c|c|}
\hline \multirow[b]{2}{*}{ Site (ID) } & \multirow[b]{2}{*}{$\begin{array}{l}\text { Geographic } \\
\text { Coordinates }\end{array}$} & \multirow[b]{2}{*}{ Site History } & \multirow[b]{2}{*}{$\begin{array}{l}\text { Soil } \\
\text { Texture }\end{array}$} & \multirow[b]{2}{*}{$\begin{array}{l}\text { Soil pH } \\
(\mathrm{SE})\end{array}$} & \multirow[b]{2}{*}{$\begin{array}{l}\text { Bulk } \\
\text { Density } \\
\text { (SE) }\end{array}$} & \multicolumn{2}{|c|}{$\begin{array}{c}\text { Mean Annual } \\
\text { Precipitation }(\mathrm{SE}) \dagger\end{array}$} & \multirow[b]{2}{*}{$\begin{array}{c}\text { Year } \\
\text { Planted/ } \\
\text { Harvested }\end{array}$} & \multirow[b]{2}{*}{$\begin{array}{c}\text { Harvested } \\
\text { Biomass } \\
\text { (SE) }\end{array}$} \\
\hline & & & & & & $\begin{array}{c}30 \text { Year } \\
\text { Mean } \\
(\mathrm{SE})\end{array}$ & $\begin{array}{c}\text { Year Planted } \\
\text { to Year } \\
\text { Harvested } \\
(\mathrm{SE}) \\
\end{array}$ & & \\
\hline $\begin{array}{l}\text { Ellerslie } \\
\text { Research } \\
\text { Station, AB } \\
\text { (ELL) }\end{array}$ & $\begin{array}{c}53^{\circ} 25^{\prime} \mathrm{N} \\
113^{\circ} 31^{\prime} \mathrm{W}\end{array}$ & $\begin{array}{l}\text { Cereal } \\
\text { crops }\end{array}$ & $\begin{array}{l}\text { Silty } \\
\text { Clay } \\
\text { Loam }\end{array}$ & $\begin{array}{c}6.0 \\
(0.1)\end{array}$ & $\begin{array}{c}1.09 \\
(0.01)\end{array}$ & $\overline{444(14)}$ & $\frac{\mathrm{mm}}{404(43)}$ & $\begin{array}{l}2005 / \\
2007\end{array}$ & $\begin{array}{l}\mathrm{Mg} \mathrm{ha}^{-1} \\
\text { N/Aף }\end{array}$ \\
\hline $\begin{array}{l}\text { Smoky Lake, } \\
\text { AB (SMO) }\end{array}$ & $\begin{array}{c}54^{\circ} 07^{\prime} \mathrm{N} \\
112^{\circ} 24^{\prime} \mathrm{W}\end{array}$ & $\begin{array}{c}\text { Tree } \\
\text { nursery }\end{array}$ & $\begin{array}{l}\text { Sandy } \\
\text { Loam }\end{array}$ & $\begin{array}{c}5.1 \\
(0.1)\end{array}$ & $\begin{array}{l}1.51 \\
(0.02)\end{array}$ & $432(13)$ & $412(27)$ & $\begin{array}{l}2005 / \\
2007\end{array}$ & $5.4(0.1)$ \\
\hline $\begin{array}{l}\text { Lakeshore Tree } \\
\text { Nursery, SK } \\
\text { (LAK) }\end{array}$ & $\begin{array}{c}52^{\circ} 00^{\prime} \mathrm{N} \\
106^{\circ} 45^{\prime} \mathrm{W}\end{array}$ & Pasture & $\begin{array}{l}\text { Silty } \\
\text { Clay } \\
\text { Loam }\end{array}$ & $\begin{array}{c}8.3 \\
(0.0)\end{array}$ & $\begin{array}{c}1.24 \\
(0.02)\end{array}$ & 349 (16) & $454(53)$ & $\begin{array}{l}2005 / \\
2007\end{array}$ & $18.4(1.2)$ \\
\hline $\begin{array}{l}\text { University of } \\
\text { Saskatchewan, } \\
\text { SK (UOS) }\end{array}$ & $\begin{array}{c}52^{\circ} 07^{\prime} \mathrm{N} \\
106^{\circ} 36^{\prime} \mathrm{W}\end{array}$ & $\begin{array}{l}\text { Cereal } \\
\text { crops }\end{array}$ & Clay & $\begin{array}{c}6.6 \\
(0.1)\end{array}$ & $\begin{array}{c}1.24 \\
(0.02)\end{array}$ & $364(17)$ & $382(74)$ & $\begin{array}{l}2006 / \\
2008\end{array}$ & $5.3(0.8)$ \\
\hline $\begin{array}{l}\text { Portage la } \\
\text { Prairie, MB } \\
\text { (POR) }\end{array}$ & $\begin{array}{l}49^{\circ} 57^{\prime} \mathrm{N} \\
98^{\circ} 10^{\prime} \mathrm{W}\end{array}$ & Vegetables & $\begin{array}{c}\text { Silt } \\
\text { Loam }\end{array}$ & $\begin{array}{c}8.3 \\
(0.0)\end{array}$ & $\begin{array}{c}1.09 \\
(0.01)\end{array}$ & $537(17)$ & $523(88)$ & $\begin{array}{l}2005 / \\
2007\end{array}$ & $22.8(3.2)$ \\
\hline $\begin{array}{l}\text { Bird's Hill, MB } \\
\text { (BIR) }\end{array}$ & $\begin{array}{l}50^{\circ} 00^{\prime} \mathrm{N} \\
97^{\circ} 00^{\prime} \mathrm{W}\end{array}$ & Pasture & $\begin{array}{l}\text { Heavy } \\
\text { Clay }\end{array}$ & $\begin{array}{c}8.3 \\
(0.1)\end{array}$ & $\begin{array}{c}1.18 \\
(0.01)\end{array}$ & $560(21)$ & $538(91)$ & $\begin{array}{l}2005 / \\
2007\end{array}$ & N/ATI \\
\hline $\begin{array}{l}\text { Sault Ste Marie, } \\
\text { ON (SSM) }\end{array}$ & $\begin{array}{l}46^{\circ} 32^{\prime} \mathrm{N} \\
84^{\circ} 24^{\prime} \mathrm{W}\end{array}$ & $\begin{array}{l}\text { Managed } \\
\text { forest }\end{array}$ & $\begin{array}{l}\text { Sandy } \\
\text { Clay } \\
\text { Loam }\end{array}$ & $\begin{array}{c}5.4 \\
(0.1)\end{array}$ & $\begin{array}{c}1.39 \\
(0.02)\end{array}$ & $914(26)$ & $826(56)$ & $\begin{array}{l}2006 / \\
2008\end{array}$ & $6.1(0.3)$ \\
\hline $\begin{array}{l}\text { Guelph, ON } \\
\text { (GUE) }\end{array}$ & $\begin{array}{l}43^{\circ} 33^{\prime} \mathrm{N} \\
80^{\circ} 13^{\prime} \mathrm{W}\end{array}$ & Turf grass & $\begin{array}{l}\text { Clay } \\
\text { Loam }\end{array}$ & $\begin{array}{c}6.9 \\
(0.0)\end{array}$ & $\begin{array}{c}1.29 \\
(0.03)\end{array}$ & $894(26)$ & $971(143)$ & $\begin{array}{c}2005 \S / \\
2008\end{array}$ & $9.5(2.5)$ \\
\hline $\begin{array}{l}\text { Pickering, ON } \\
\text { (PIC) }\end{array}$ & $\begin{array}{l}44^{\circ} 00^{\prime} \mathrm{N} \\
79^{\circ} 01^{\prime} \mathrm{W}\end{array}$ & $\begin{array}{l}\text { Idle / Failed } \\
\text { plantation }\end{array}$ & Clay & $\begin{array}{c}6.8 \\
(0.2)\end{array}$ & $\begin{array}{c}1.22 \\
(0.03)\end{array}$ & 887 (18) & 948 (131) & $\begin{array}{l}2006 / \\
2008\end{array}$ & $14.0(2.1)$ \\
\hline
\end{tabular}


Table 2 Pearson product-moment correlations for climate variables modeled with BioSIM and harvested biomass for seven S. purpurea 'Hotel' plantations (SMO, LAK, UOS, POR, SSM, GUE, PIC)

\begin{tabular}{lcc}
\hline & $\mathrm{r}$ & $P$ \\
\hline Degree days (base $5^{\circ} \mathrm{C}$ ) & 0.398 & 0.377 \\
Degree days (base $10^{\circ} \mathrm{C}$ ) & 0.425 & 0.341 \\
Annual precipitation & -0.058 & 0.902 \\
Summer precipitation (3 years) & 0.256 & 0.579 \\
Summer precipitation (First 2 years) & 0.752 & 0.051 \\
Thornwaite potential evapotranspiration & 0.543 & 0.208 \\
Standard Thornwaite potential evapotranspiration & 0.343 & 0.452 \\
Vapor pressure deficit & -0.080 & 0.865 \\
Aridity index & 0.236 & 0.446 \\
\hline
\end{tabular}


Table 3 Pearson product-moment correlations for measured soil variables and harvested biomass for seven S. purpurea 'Hotel' plantations (SMO, LAK, UOS, POR, SSM, GUE, PIC)

\begin{tabular}{|c|c|c|c|c|}
\hline & \multicolumn{2}{|c|}{$0-20 \mathrm{~cm}$} & \multicolumn{2}{|c|}{$20-40 \mathrm{~cm}$} \\
\hline & $\mathrm{r}$ & $P$ & $\mathrm{r}$ & $P$ \\
\hline $\mathrm{pH}$ & 0.886 & 0.005 & 0.804 & 0.023 \\
\hline Organic C & 0.882 & 0.006 & 0.897 & 0.004 \\
\hline Total N & 0.743 & 0.048 & 0.380 & 0.394 \\
\hline $\mathrm{C}: \mathrm{N}$ ratio & 0.259 & 0.570 & 0.497 & 0.073 \\
\hline $\mathrm{H}_{2} \mathrm{SO}_{4}$ extractable $\mathrm{P}$ & 0.479 & 0.268 & 0.414 & 0.349 \\
\hline \multicolumn{5}{|l|}{ Bulk chemistry } \\
\hline Total Ca & 0.967 & 0.000 & $--\dagger$ & -- \\
\hline Total Mg & 0.925 & 0.002 & -- & -- \\
\hline Total Al & 0.385 & 0.387 & -- & -- \\
\hline Total Fe & 0.403 & 0.363 & -- & -- \\
\hline Total Si & -0.785 & 0.030 & -- & -- \\
\hline Total K & 0.340 & 0.449 & -- & -- \\
\hline Total P & 0.637 & 0.114 & -- & -- \\
\hline \multicolumn{5}{|l|}{ Exchangeable Cations } \\
\hline $\mathrm{K}$ & 0.473 & 0.276 & 0.132 & 0.777 \\
\hline $\mathrm{Ca}$ & 0.891 & 0.005 & 0.858 & 0.004 \\
\hline $\mathrm{Mg}$ & -0.426 & 0.333 & -0.412 & 0.352 \\
\hline $\mathrm{Na}$ & -0.412 & 0.351 & -0.403 & 0.362 \\
\hline $\mathrm{Fe}$ & -0.492 & 0.253 & -0.506 & 0.238 \\
\hline $\mathrm{Al}$ & -0.548 & 0.193 & -0.412 & 0.351 \\
\hline Sand content & -0.698 & 0.072 & -0.164 & 0.723 \\
\hline Silt content & 0.922 & 0.002 & 0.793 & 0.027 \\
\hline Clay content & 0.144 & 0.755 & -0.377 & 0.398 \\
\hline
\end{tabular}

$\dagger$ not included in analyses 
Table 4 Pearson product-moment correlations for measured foliar variables and harvested biomass for seven $S$. purpurea 'Hotel' plantations (SMO, LAK, UOS, POR, SSM, GUE, PIC)

\begin{tabular}{lcccccc}
\hline & $\begin{array}{c}\text { All sites (SMO, LAK, UOS, } \\
\text { POR, SSM, GUE, PIC) }\end{array}$ & \multicolumn{2}{c}{$\begin{array}{c}\text { Water stressed sites excluded } \\
\text { (LAK, POR, SSM, GUE, PIC) }\end{array}$} & \multicolumn{2}{c}{$\begin{array}{c}\text { Water, N, K stressed sites } \\
\text { excluded (LAK, POR, PIC) }\end{array}$} \\
\cline { 2 - 7 } & $\mathrm{r}$ & $P$ & $\mathrm{r}$ & $P$ & $\mathrm{r}$ & $P$ \\
\hline Stems & & & & & & \\
$\delta^{13} \mathrm{C}$ & -0.288 & 0.526 & & & & \\
Leaves & & & & & & \\
$\quad$ Nitrogen & 0.103 & 0.825 & 0.811 & 0.075 & & \\
$\quad$ Potassium & 0.621 & 0.127 & 0.938 & 0.009 & & \\
Calcium & 0.444 & 0.311 & -0.245 & 0.684 & -0.705 & 0.425 \\
Magnesium & -0.457 & 0.294 & -0.544 & 0.324 & 0.928 & 0.130 \\
Phosphorus & -0.063 & 0.893 & 0.070 & 0.910 & -0.764 & 0.358 \\
\hline
\end{tabular}




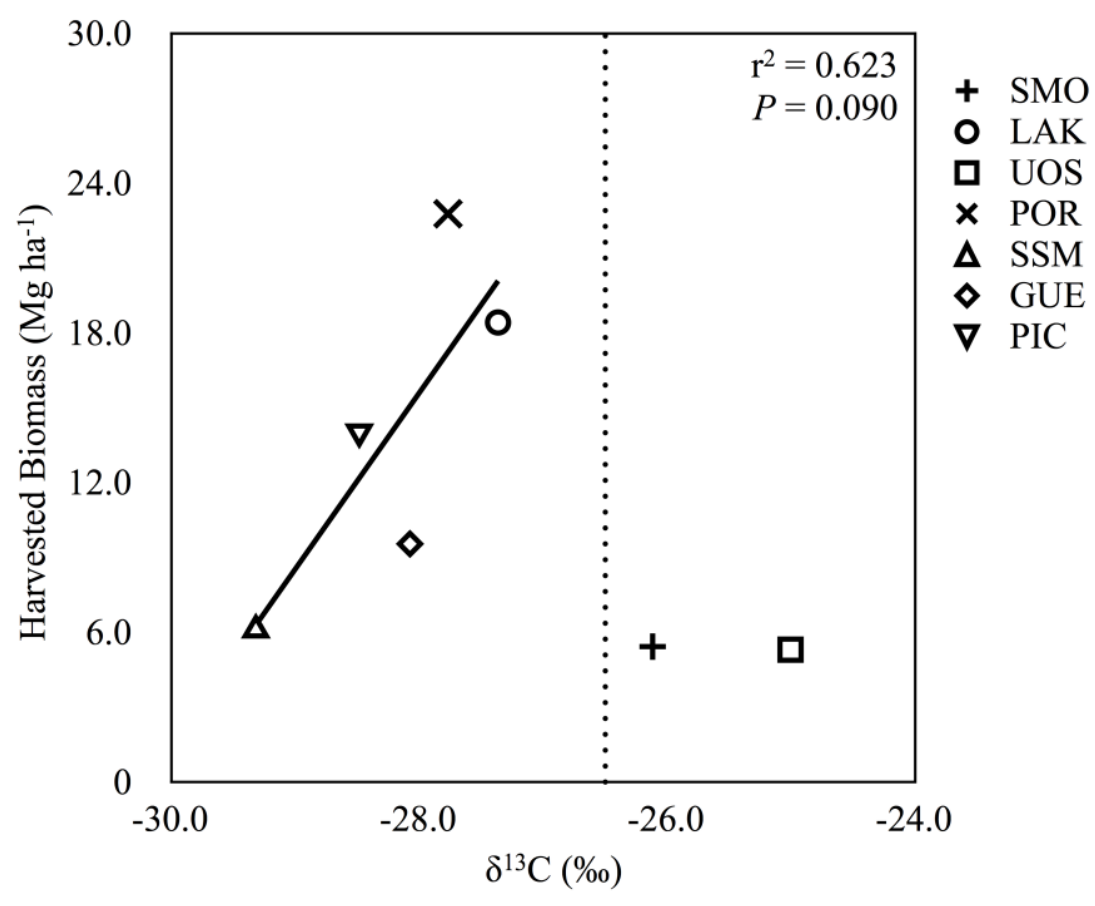

Fig. 1 Relationship between $\delta^{13} \mathrm{C}$ of stems vs. harvested biomass for seven S. purpurea 'Hotel' plantations (SMO, LAK, UOS, POR, SSM, GUE, PIC). Less negative $\delta^{13} \mathrm{C}$ values (towards right) indicate increasing water use efficiency and/or water stress. Dashed line represents approximate threshold for acute water stress. Regression excludes SMO and UOS as these sites are beyond the threshold for acute water stress and therefore are a distinct population from the remaining dataset. 

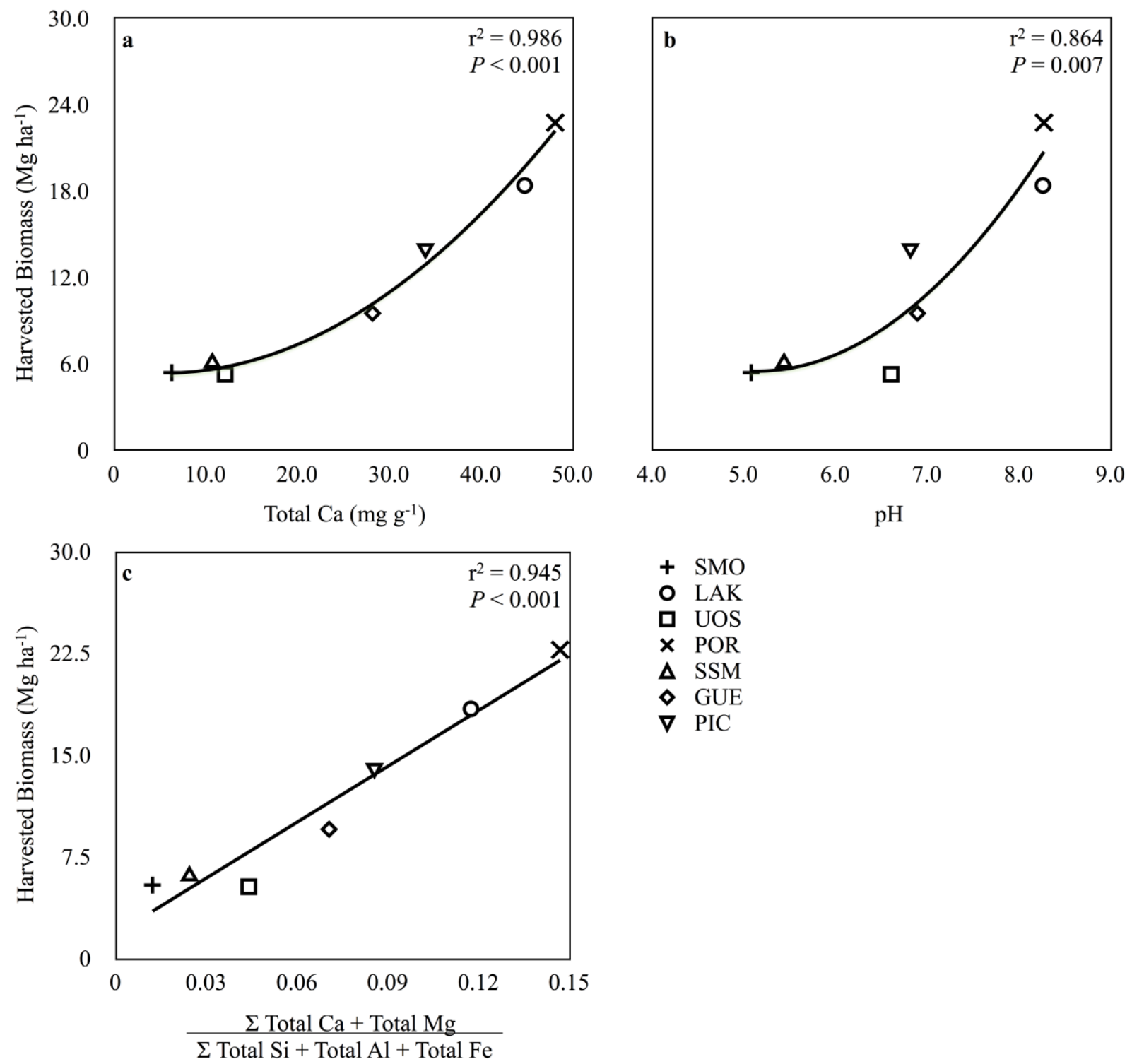

$\begin{array}{ll}+ & \text { SMO } \\ \text { ㅇ } & \text { LAK } \\ \text { ㅁ } & \text { UOS } \\ \boldsymbol{x} & \text { POR } \\ \boldsymbol{\Delta} & \text { SSM } \\ \diamond & \text { GUE } \\ \boldsymbol{\nabla} & \text { PIC }\end{array}$

Fig. 2 Relationship between total $\mathrm{Ca}(\mathrm{a}) \mathrm{pH}$ (b) and $\Sigma$ Total $\mathrm{Ca}+$ Total $\mathrm{Mg} / \Sigma$ Total Si + Total $\mathrm{Al}+$ Total Fe (c) of top 0-20 cm of soil vs. harvested biomass for seven S. purpurea 'Hotel' plantations (SMO, LAK, UOS, POR, SSM, GUE, PIC). 

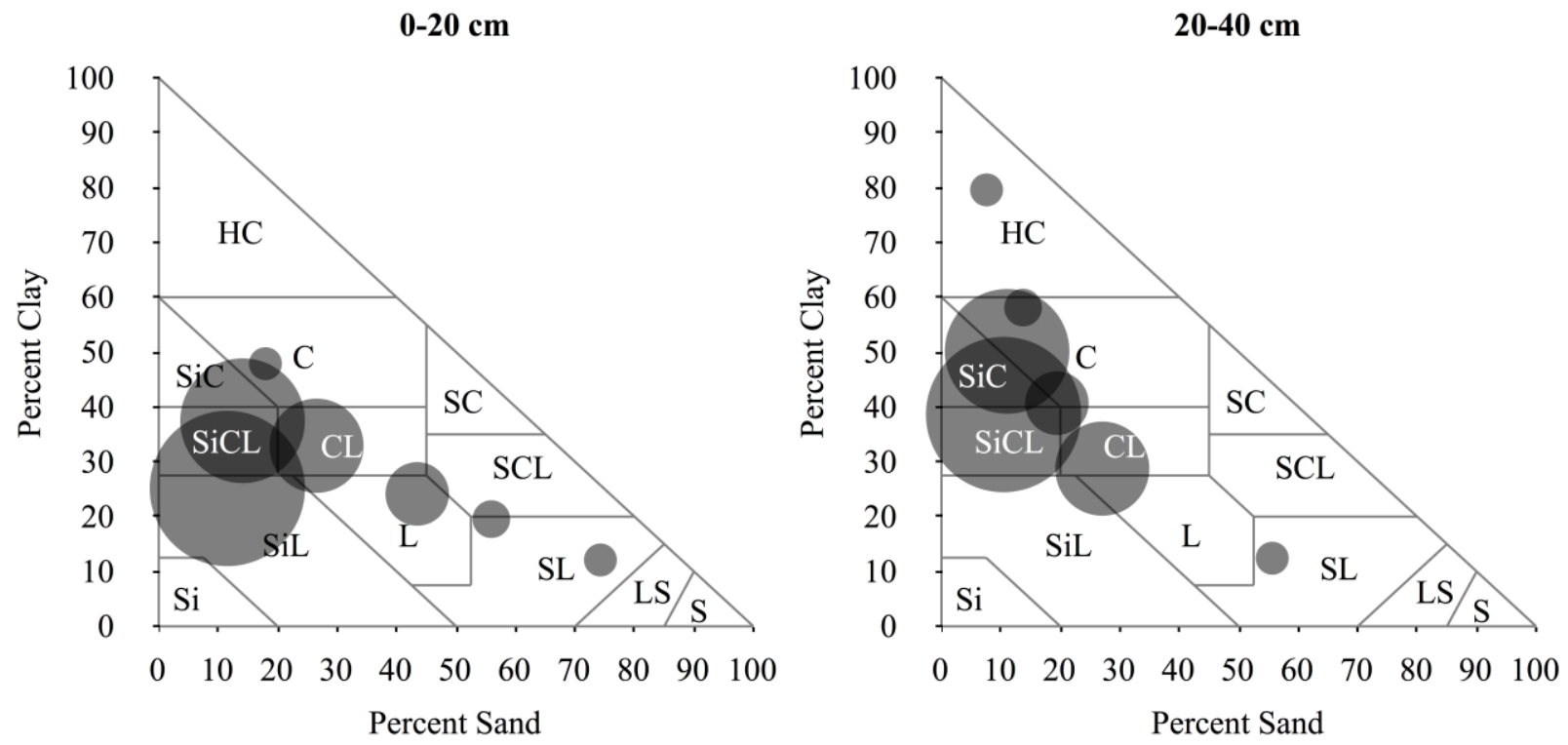

Fig. 3 Soil texture (Soil Classification Working Group 1998) in relation to harvested biomass for seven S. purpurea ‘Hotel' plantations (SMO, LAK, UOS, POR, SSM, GUE, PIC). Larger circles indicate higher harvested biomass. 

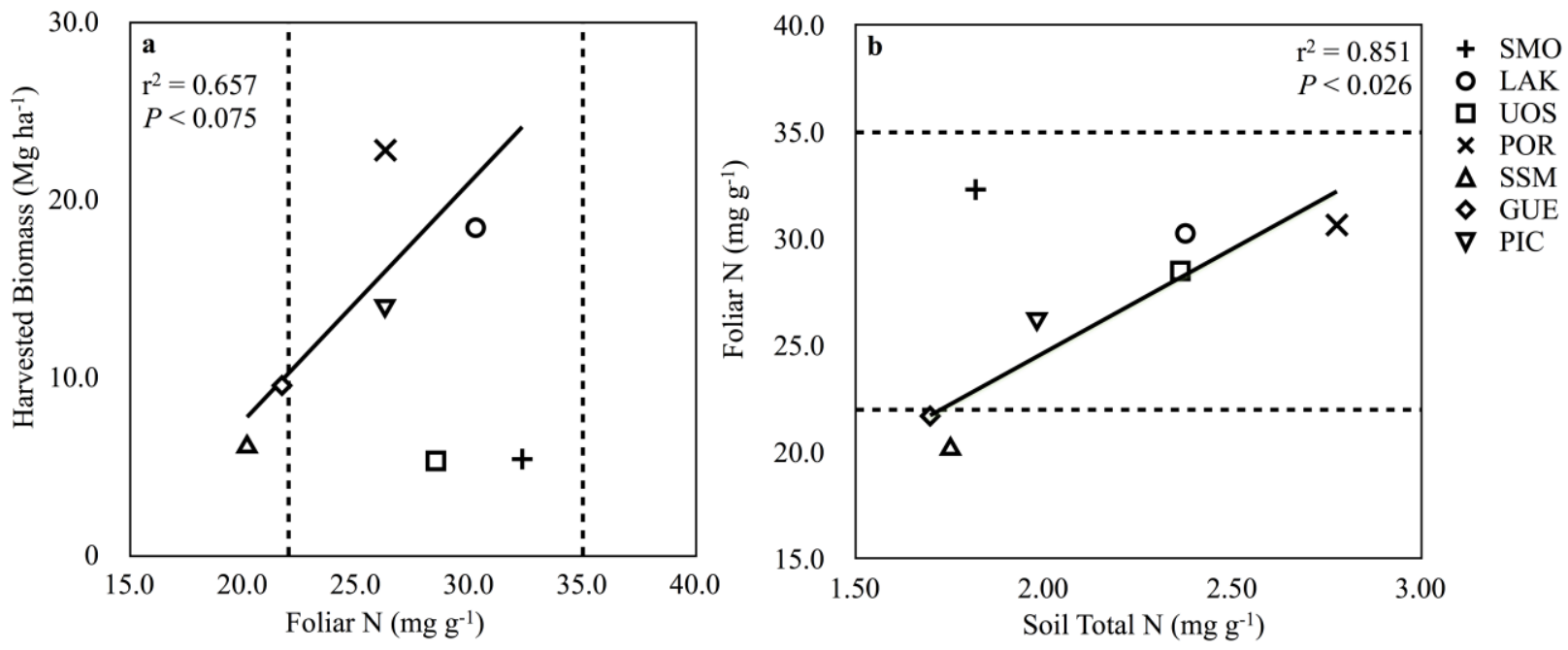

Fig. 4 Relationship between $\mathrm{N}$ availability and productivity expressed as foliar $\mathrm{N}$ (a) vs. harvested biomass for seven S. purpurea 'Hotel' plantations (SMO, LAK, UOS, POR, SSM, GUE, PIC), and soil total $\mathrm{N}$ vs. foliar $\mathrm{N}$ in the upper $20 \mathrm{~cm}$ of soil (b) for all nine plantations (adding ELL and BIR). Due to water stress, UOS and SMO sites do not share benefit from increasing $\mathrm{N}$ uptake and, as such, are excluded from the regression dataset. Dashed lines represent low and high of range of optimal concentrations of foliar N for other Salix species (22$35 \mathrm{mg} \mathrm{g}^{-1}$ ) as reported by Simon et al. (1990) and Kopinga and van den Burg (1995). 

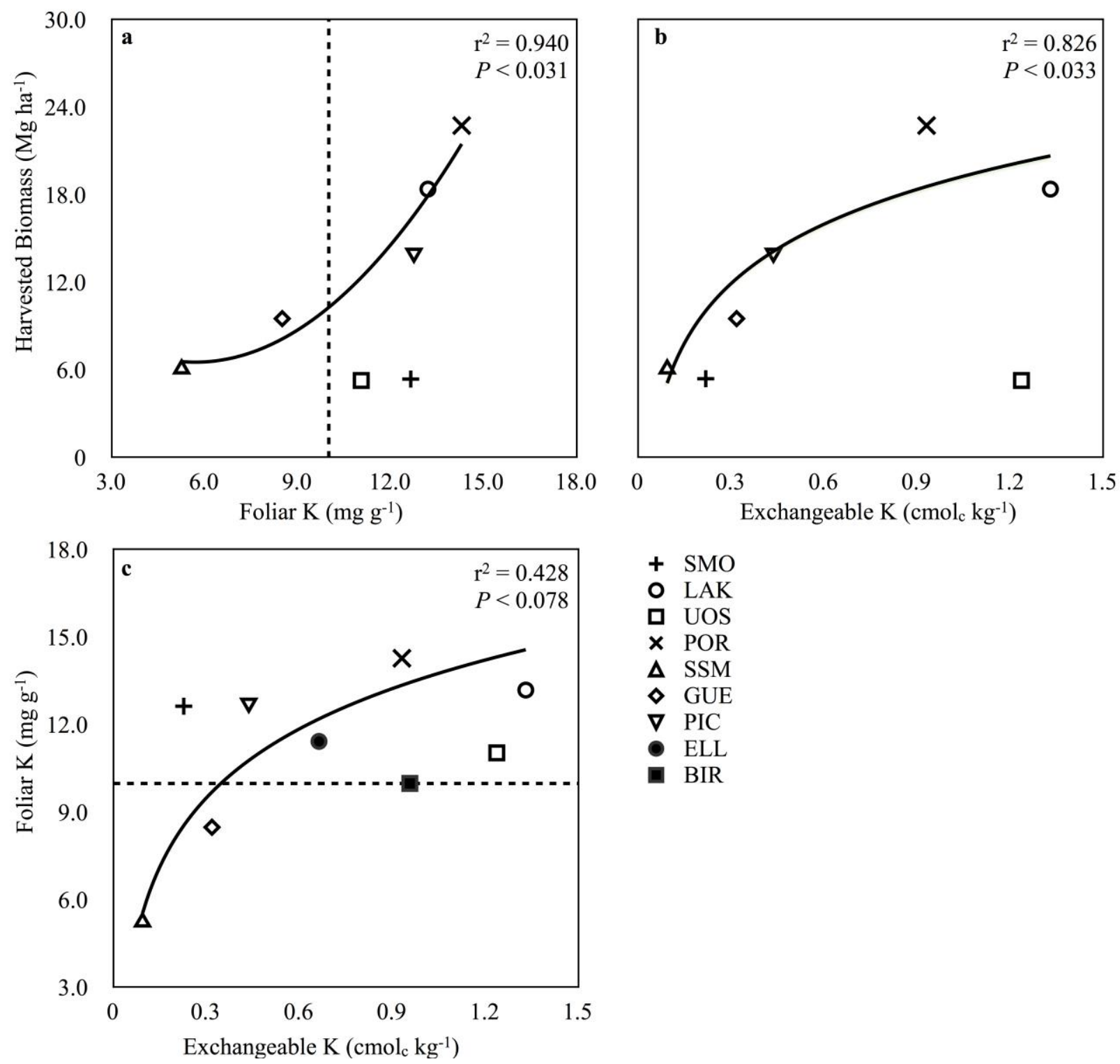

Fig. 5 Relationship between $\mathrm{K}$ availability and productivity expressed as foliar K (a) and soil exchangeable K (0-20 cm) (b) vs. harvested biomass for seven S. purpurea 'Hotel' plantations (SMO, LAK, UOS, POR, SSM, GUE, PIC), and soil exchangeable K (0-20 cm) vs. foliar K (c) for all nine plantations (adding ELL and BIR). Due to water stress, UOS and SMO sites do not share benefit from increasing $\mathrm{K}$ uptake and, as such, are excluded from the regression datasets (a,b). Minimum threshold for foliar $\mathrm{K}\left(10 \mathrm{mg} \mathrm{g}^{-1}\right)$ is indicated by dashed lines (Mengel 2007). 

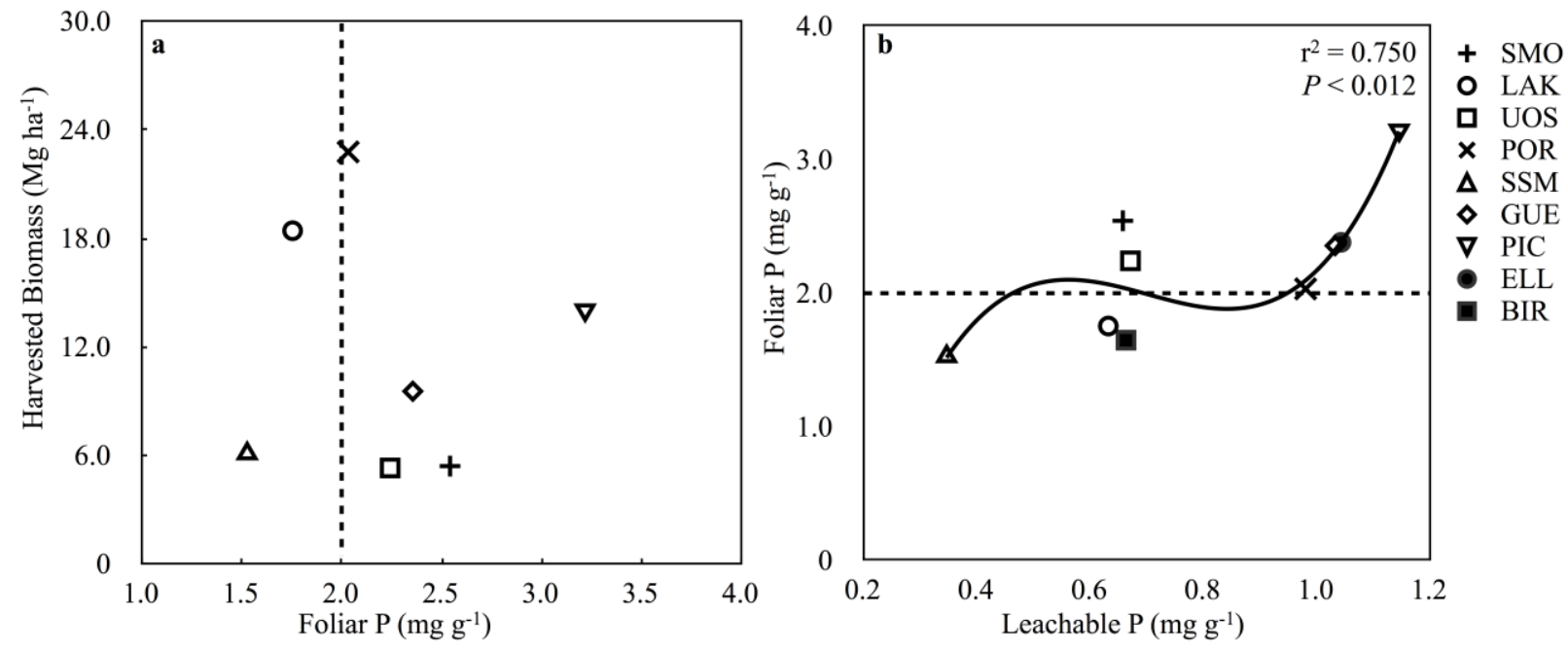

Fig. 6 Relationship between $\mathrm{P}$ availability and productivity expressed as foliar $\mathrm{P}$ vs. harvested biomass for seven S. purpurea 'Hotel' plantations (SMO, LAK, UOS, POR, SSM, GUE, PIC) (a), and leachable soil P (0-20 cm) vs. foliar P (b) for all nine plantations (adding ELL and BIR). Dashed line represents apparent approximate sufficiency for P (Simon et al. 1990). 